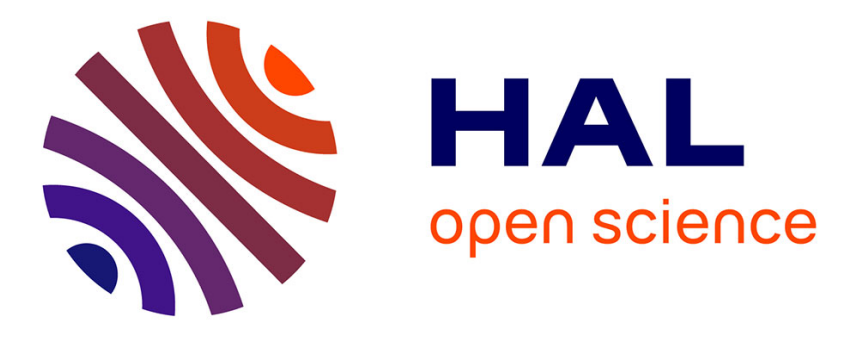

\title{
Health Impact of Electric Vehicles Considering Environmental Leakage. The Case Study on Japan, China, UK and Poland
}

Kamila Romejko, Masaru Nakano

\section{- To cite this version:}

Kamila Romejko, Masaru Nakano. Health Impact of Electric Vehicles Considering Environmental Leakage. The Case Study on Japan, China, UK and Poland. IFIP International Conference on Advances in Production Management Systems (APMS), Sep 2017, Hamburg, Germany. pp.390-398, 10.1007/978-3-319-66926-7_45. hal-01707301

\section{HAL Id: hal-01707301 \\ https://hal.inria.fr/hal-01707301}

Submitted on 12 Feb 2018

HAL is a multi-disciplinary open access archive for the deposit and dissemination of scientific research documents, whether they are published or not. The documents may come from teaching and research institutions in France or abroad, or from public or private research centers.
L'archive ouverte pluridisciplinaire HAL, est destinée au dépôt et à la diffusion de documents scientifiques de niveau recherche, publiés ou non, émanant des établissements d'enseignement et de recherche français ou étrangers, des laboratoires publics ou privés.

\section{(ㄷ)(i)}

Distributed under a Creative Commons Attribution| 4.0 International License 


\title{
Health impact of Electric Vehicles considering environ- mental leakage. The case study on Japan, China, UK and Poland.
}

\author{
Kamila Romejko, Masaru Nakano \\ The Graduate School of System Design and Management, Keio University Kyosei Building, 4- \\ 1-1, Hiyoshi, Kohoku-ku, Yokohama, Kanagawa, 223-8526, Japan \\ kamilarr@gmail.com, nakano@sdm.keio.ac.jp
}

\begin{abstract}
In recent years the topic of air pollution is gaining more attention due to the health effects its has on human lives. At the same time, we can observe popularization of Electric Vehicles (EVs), due to their environmental and economic benefits. However, a few studies suggest that EVs might be not environmental friendly in the long term. Hence, there is a need to investigate the emissions produced by EVs and the monetary cost of them on the health. This paper aims to quantify the cost of health diseases by employing life cycle assessment of EVs in Japan, China, Poland and the United Kingdom. The results of the study imply that the total cost of health issues is lower when import of $\mathrm{EVs}$ is from the nearby countries, which generate electricity from clean energy resources or when it is produced in a low emission country locally.
\end{abstract}

Keywords: Production, Electric Vehicles, Life Cycle Assessment, Health Issues, Emissions, Air pollution

\section{Introduction}

Air pollution is one of the top greatest risk factors for human health. According to pundits, roughly 6.5 million premature deaths are the aftermath of air pollution [1]. The cost of the health problems originating from air pollution stood at $\$ 330-940 \mathrm{~B}$ in 2010 for European Union [2]. Industry, power plants, households, transport, agriculture and waste treatment are human-made sources of air pollution [1]. Inefficient fuel combustion, residential heating, vehicles exacerbate the impact of emissions [3].

Those activities cause emissions e.g. sulfur oxides $\left(\mathrm{SO}_{2}\right)$, particulate matter (PM) and nitrogen oxides $\left(\mathrm{NO}_{\mathrm{x}}\right)$. More than a quarter of total energy-related emissions of $\mathrm{SO}_{2}$ are made in China [1]. Transportation attributes to over $50 \%$ of all energy-related emission of $\mathrm{NO}_{\mathrm{x}}$. For instance, only in China, more than 1 million premature deaths were recorded due to outdoor air pollution caused by particulate matter. In the European Union, more than 175,000 were recorded due to outdoor air pollution caused by PM. At the same time, it was more than 1 million in China [1]. In 2014 in Cracow (Poland), there were 188 days, in which PM was higher than advised $50 \mu \mathrm{g} / \mathrm{m} 3$. In January 2017, in Warsaw (Poland), the PM level was seven times above the secure PM level described by World Health Organization (WHO) [4]. According to [5], the 
most common impacts of pollutants are chronic mortality and acute and chronic morbidity, which are caused by i.e. respiratory problems, asthma, cardio-pulmonary, leukaemia, ear infections etc. In this study $\mathrm{SO}_{2}, \mathrm{PM}$ and $\mathrm{NO}_{x}$ are investigated, because they are the main pollutants, which damage cost is the highest among all primary pollutants [5]. Moreover, there are international standards in road transportation for the emission of those pollutants [5].

Alternative Fuel Vehicles (AFVs) are getting attention due to their environmental and economic advantages. However, there is a need to investigate the benefits and impact of AFVs during not only use phase, but at stake is the total lifecycle assessment of these vehicles. Wide studies have investigated the introduction, proliferation and portfolio of AFVs [6-9]. Only a few of papers have focused on the impact of AFVs on air pollution. However, most of the studies focus on GHG emissions and neglect other pollutants e.g. $\mathrm{SO}_{2}, \mathrm{PM}$ and $\mathrm{NO}_{\mathrm{x}}[10,11]$. A Life Cycle Assessment (LCA) study by Hawkins et.al [12] provided a thorough analysis of EV over their total life cycle and their impact on different environmental categories. Nevertheless, the health impact of EVs was not considered in that research [12]. Health effects are neglected in most of the studies, only $[13,14]$ conducted the analysis while incorporating the effects of vehicles on health issues. However, the before-mentioned studies concentrate on only one country, China. Moreover, most of the papers investigate only one stage of vehicle's lifecycle, mostly usage $[7,15]$. In this paper, we consider environmental leakage, which happens when rich country imports dirty products from developing countries. This phenomenon leads to displacement of emissions abroad and often an increase in the global pollution [16]. According to [17], the consumption-based approach is necessary to calculate the impact of production activities. There has been no study conducted on environmental leakage and the production of AFVs. Therefore, there is a necessity to examine the above-mentioned gaps. Hence, in this study, we quantify environmental leakage according to consumption-based approach and base the calculations on 'who consumes the product'. Therefore, the objective of this study is that it estimates the health effects cost of EVs throughout the total lifecycle and compares it among several countries while taking into consideration environmental leakage. This study might help governments and producers while making crucial decisions for long-term investments. The results might encourage switching to EVs, and in order to do that, governments can implement either subsidy or environmental tax deduction. For this purpose, governments need to create target for policy creation, which was already studied by $[6,18]$. The case study was conducted on Japan, China, Poland and the United Kingdom (UK). According to [19], China, UK and Japan are the countries with the largest EV sales and market share till 2015. Moreover, China was the largest market for electric cars with over 200000 new registrations [19]. However, in China, most of electricity is produced from coal and according to [20] EVs could hinder health and the environment quality [20]. Japan is a country, which produces Nissan Leaf, the Nissan LEAF, which is the world's best-selling EV[21]. The United Kingdom is not a main automotive producer, but invites investment from manufacturers, moreover its electricity mix consist of high percentage of renewables [22]. On the other hand, Poland's electricity is based on coal and the air pollution is high. Poland has just established an "Electromobility Development Plan for Poland", 
which implies that till 2025 there will be a million EVs on the polish roads. The government of Poland is also interested in investment in automotive industry [23]. Section 2 explains the LCA method for evaluation of health cost of EVs. The results and discussion are presented in Section 3. Finally, Section 4 concludes the research.

\section{$2 \quad$ Methods}

\subsection{Life cycle assessment outline}

The LCA is the most broadly used tool for analyzing vehicles throughout different stages of their lifetime. This method was used in this paper to quantify the health impact of EVs during their manufacturing stage, transport, use phase and end of life stage. The case study was conducted for four countries and includes environmental leakage issues. In line with it, we calculate 16 cases of vehicle life cycle. EVs are used during a 10-year period. Moreover, the scenarios for 2016 and 2025 are being investigated as well in order to compare the improvements in the technologies. The evaluation formula of LCA is shown in Eqs. (1)-(5).

$$
\begin{gathered}
L C A_{e, k}^{\text {total }}(y)=\left(L C A_{e, k}^{\text {prod }}(y)+L C A_{e, k}^{\text {trans }}(y)+L C A_{e, k}^{u s e}(y)+L C A_{e, k}^{E} L\right. \\
L C A_{e, k}^{\text {prod }}(y)=\sum_{m} n_{m, k}(y) \times C_{k}(y) \times E_{e, m, k}(y) \times P H_{e} \\
L C A_{e, k}^{\text {trans }}(y)=F(y) \times E_{\text {diesel }}(y) \times P T_{e} \times D_{k} \\
L C A_{e, k}^{u s e}(y)=\sum_{m} n_{m, k}(y) \times C_{k}(y) \times E_{e, m, k}(y) \times P H_{e} \times M_{k} \\
L C A_{e, k}^{E o L}(y)=\sum_{m} n_{m, k}(y) \times C_{k}(y) \times E_{e, m, k}(y) \times P H_{e}
\end{gathered}
$$

$e$ : emission type $\left[\mathrm{NO}_{\mathrm{x}}, \mathrm{SO}_{2}, \mathrm{PM}\right]$

$k$ : country investigated (Japan/ China/ UK/Poland)

$n$ : energy ratio (Japan/ China/ UK/Poland)

$y$ : year [2016-2025]

$m$ : type of energy used (coal, nuclear, gas, etc.)

$C$ : energy consumption [kWh]

$E$ : air emissions of $\mathrm{NO}_{\mathrm{x}}, \mathrm{SO}_{2}, \mathrm{PM}$ from energy production[kg per $\mathrm{kWh}$ ]

$\mathrm{M}$ : mileage $[\mathrm{km}]$

R: production rate [units]

$F$ : energy used to transport one vehicle on a diesel MSD ship per km [kWh per km]

$E_{\text {diesel }}$ : air emissions of $\mathrm{NO}_{\mathrm{x}}, \mathrm{SO}_{2}, \mathrm{PM}$ from energy production in MSD ferry ship [kg per kWh]

$D$ : distance in ferry transportation $[\mathrm{km}]$ 
$\mathrm{PH}_{e}$ : Monetary damage conversion cost of high-height emissions (energy production) [€ per $\mathrm{kg}$ ]

$P L_{e}$ : Monetary damage conversion cost of low-height emissions cost (transportation) [€ per kg]

$P T_{e}$ : Monetary damage conversion cost of diesel ship transportation emissions cost [€ per kg]

$L C A_{e, k}^{\text {total }}$ - stands for total cost $[€] ; L C A_{e, k}^{\text {prod }}$ - cost in manufacturing phase [€];

$L C A_{e, k}^{\text {trans }}$ - cost in transportation [€]; $L C A_{e, k}^{\text {use }}$ - cost in use phase [€]; $L C A_{e, k}^{E o L}$ - cost in End of Life phase [€]

Due to size limitation of this paper, the detailed description of methods and data used in LCA are described in details in [3] paper. The changes and additional data gathered for the model are defined in the below sections. Furthermore, we are considering environmental leakage and therefore we use consumer-base approach [17], which assumes that consumers are bearing the full responsibility for the impacts of producing the goods they consume. Due to the above, we are taking into consideration the total emissions that were produced i.e. manufacturing and transportation and add them to the cost of the importing country.

\subsection{Electricity mix, emissions, cost, vehicle assumptions, transport}

The data for China, UK and Japan were taken from IEA for both the present situation and the future forecast [22]. IEA predicts scenario for Europe as a whole, which is an inaccurate scenario for Poland, since the electricity mix is based on coal. In view of this fact, we use the forecast conducted by the Polish government [24].

Emissions from electricity generated from coal for Poland were taken from IEA [25] The government implemented new emission standards for coal from 2016. The future emissions from electricity generated from coal were adjusted to the UK levels.

The emission cost for both electricity production and use phase of EVs were gathered in the previous study [3]. Emission prices for maritime transportation were calculated as an average price of the available damage cost of pollutants in sea regions [5].

The basic assumptions correspond to the previous study published in [3]. The EV under review is Nissan Leaf, with a $24 \mathrm{kWh}$ Lithium-Ion batter. For this case study, we assume no battery replacement in the 10year usage period, since the Nissan Leaf guarantees the battery for around $160,000 \mathrm{~km}$ [26]. Annual average vehicle mileage differs among the case study countries. For China it is 14,496 km [27], for Japan $9,300 \mathrm{~km}$ [28], UK 12,713km [29] and 8,257 km in Poland [30]. Since the data do not distinguish types of vehicles, we assume that the distance is same for all types of passenger vehicles.

Global transport of large quantities of new vehicles is primarily carried by ships. We calculate the emissions produced during transportation from the main port of dispatch to the main port of arrival. For Japan, the port of entry is Yokohama, for the UK is Bristol, for China is Shanghai and Gdańsk for Poland. The distance is calculated according to data from [31]. The assumption is, that the shipping takes place on Roll On Roll Off (RORO) base [32], which capacity is 7,200 EV vehicles [33]. This type of vessel is used to due to the fact that most of the vehicle producers use this type of shipment in order to maximize capacity and minimize time. The $\mathrm{g} / \mathrm{kWh}$ emissions of medium speed diesel vessel (MSD) were taken from [34] and the energy cost in $\mathrm{kWh} / \mathrm{t}-\mathrm{km}$ of freight-transport was based on [35]. 


\section{$3 \quad$ Results and discussion}

The comparisons of results for the 16 cases of vehicle life cycle are presented in Fig. 2 and Fig. 3 below.

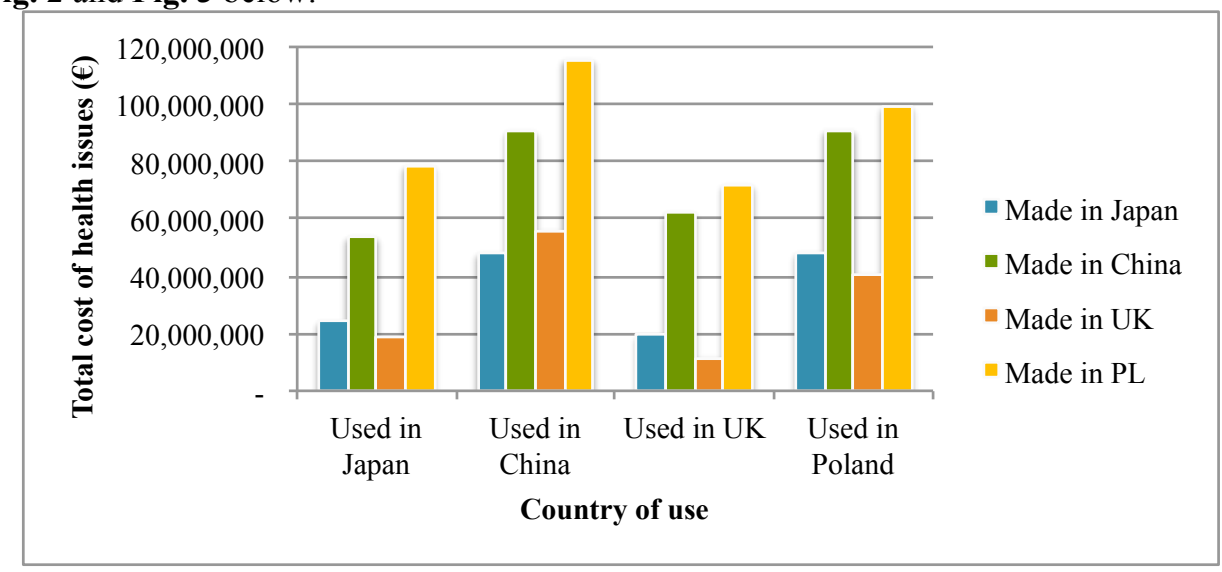

Fig. 1 Total health cost associated with EV life cycle (production in 2016)

The findings from Fig. 2 and Fig. 3 clearly present the fact that if we consider environmental leakage, import and export of EVs is not justified in some situations e.g. where emissions during manufacturing are high or the distance between the countries is substantial. According to the outcome of the research, the production and use of vehicles in the UK contribute to the lowest health cost among all 16 cases analyzed for both 2016 and 2025. Provided that, it would be advised to set the production of EVs in the UK due to the advantageous electricity mix and the proximity to other European markets. It is seen, from the Fig. 2, that for Poland, the apt solution would be to import the EVs from the UK in 2016. In this situation, the total health cost that Poland would have to bear stands at around $€ 40 \mathrm{M}$. In contrast, there was a $95 \%$ decrease in the case of the production and use of the EVs in Poland from 2016 to 2025. The slump of the total monetary cost can be explained by the fact that improvement in electricity production technologies and the change of the electricity mix in Poland takes place. Moreover, the driving distance in Poland is shorter than in the UK. In China, for both 2016 and 2025 scenario, the most appropriate solution would be to import the EVs from Japan due to the short distance and the lower emissions of pollutants in Japan. Surprisingly, in Japan in 2016, the lowest total health cost would take place in the scenario when EVs are imported from the UK. This has a reflection in the change of electricity mix in Japan after Tohoku Earthquake in 2011. Instead of nuclear energy, Japan is using a higher percentage of gas and coal for electricity generation. In 2025 in all cases, the total monetary cost of health diseases drops dramatically due to significant improvement in electricity production, technology efficiency of vehicle and battery production, and new standards for air pollution. The most substantial decrease in terms of value can be noted in the case of producing the EVs in Poland and exporting them to China. This case scenario is worth around $€ 115 \mathrm{M}$ in 2016 and no more than $€ 18.5 \mathrm{M}$ in 2025 . Another interesting aspect that emerges from analyzing the data is that during the maritime transportation the emission of air pollutants 
is significant. The analysis showed that only the transportation of an EV from Japan to Poland in 2016 accounted for almost $20 \%$ of total lifecycle emissions of $\mathrm{NO}_{\mathrm{x}} 13 \%$ of $\mathrm{SO}_{2}$ and $55 \%$ of PM. In terms of the import of an EV from Japan to the UK in 2016 , those results were even higher and amounted to $30 \%$ of $\mathrm{NO}_{\mathrm{x}}, 43 \%$ of $\mathrm{SO}_{2}$ and $76 \%$ of PM. The result from this study can be substantiated by the data from [36], which shows that a ship can emit around 5,000 tons of $\mathrm{SO}_{2}$ annually.

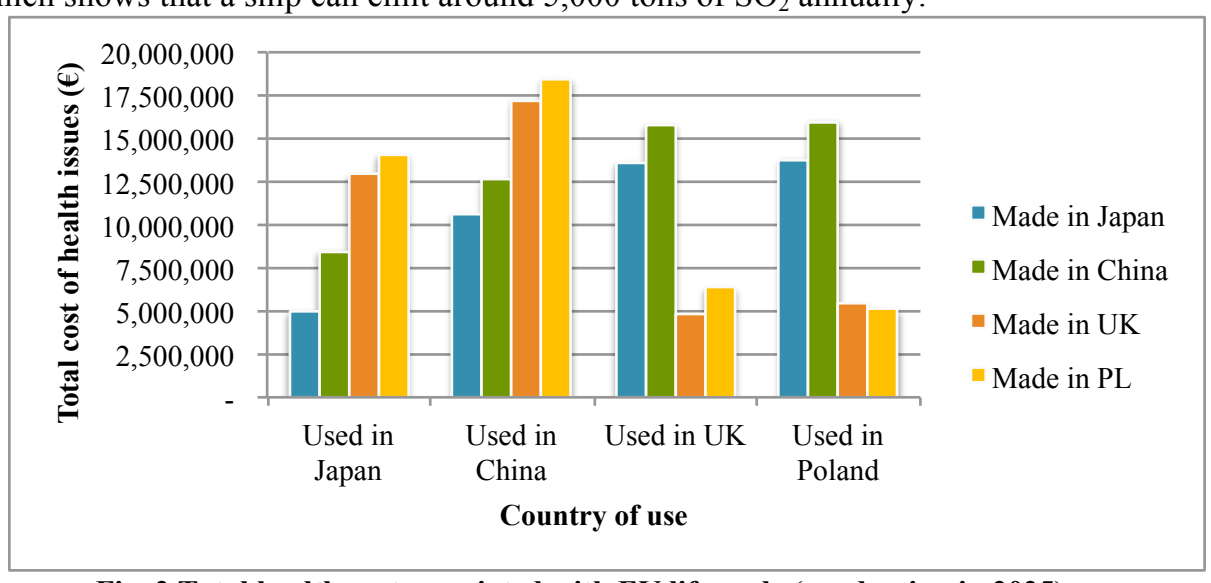

Fig. 2 Total health cost associated with EV life cycle (production in 2025)

The author of the previous-mentioned study asserts that one container ship can produce "almost the same amount of cancer and asthma-causing chemicals as $50 \mathrm{M}$ cars" [36].

\section{Conclusions}

To sum up, the majority of human-made air pollution originates from energy use and production, combustion of biomass and fossil fuels [1]. Health problems associated with the aftermaths of air pollution are causing a considerable monetary cost for the global economy. In this study, we believe that developed countries, producers and consumers and are to be blamed for the aftermaths of the environmental leakages. Developing countries imports dirty products and this lead to displacement of emissions abroad and often an overall increase in the global pollution [16]. Hence, the present study was designed to determine the cost of health problems associated with air pollution, while incorporating environmental leakage. In this research, the rich countries carry the cost of locating production in developing countries and pay the abatement cost back to producing countries. The numerical results of this study prove our concern about environmental leakage and the danger of importing the products from developing countries. This study has found that it is advisable to keep local production if the country's electricity is generated from the clean energy source. Additionally, if the electricity mix is unfavorable, it is recommended to import from a nearby-located country of a clean electricity mix.

There is a strong need for further regulations and implementation of standards for not only vehicle transportation emission but also maritime transportation. It is also 
recommended to switch from using marine diesel to ships fueled by liquefied natural gas (LNG), this can considerably reduce not only $\mathrm{SO}_{2}$ but also PM emissions. At stake is implementing regulations, global policy towards decreasing the air emission level, and unification of the alarming standards. Furthermore, it is also crucial to note that this paper has only analyzed the cost of the health from production, transport and use of EVs. If the cost of GHG emissions would be analyzed the final result would differ. Further improvements in the study could investigate a broader view and include total sustainability analysis of EVs' impact.

\section{$5 \quad$ References}

1. International Energy Agency (2016) Energy and Air Pollution. World Energy Outlook - Spec Rep. doi: 10.1021/ac00256a010

2. EC (European Commission) (2013) Clean Air Policy Package,SWD(2013) 531 final. doi: $\operatorname{SWD}(2013) 93$

3. Romejko K, Nakano M (2017) Life Cycle Analysis of Emissions from Electric and Gasoline Vehicles in Different Regions (to be published). Int. J. Autom. Technol. 11:

4. (2017) Smog in Poland. In: Polish Smog Alarm Website (Polski Alarm Smogowy). http://www.polskialarmsmogowy.pl/index/smogwpolsce.

5. Korzhenevych A, Dehnen N, Bröcker J, Holtkamp M, Meier H, Gibson G, Varna A, Cox V (2014) Update of the Handbook on External Costs of Transport. Eur Comm DG Mobil Transp. doi: Ref: ED 57769 - Issue Number 1

6. Nonaka T, Nakano M (2011) Carbon Taxation Using LCCO2 and LCC for Clean Energy Vehicles. Trans Japan Soc Mech Eng 77:4024-4032.

7. Brady J, O'Mahony M (2011) Travel to work in Dublin. The potential impacts of electric vehicles on climate change and urban air quality. Transp Res Part D Transp Environ 16:188-193. doi: 10.1016/j.trd.2010.09.006

8. Zhao X, Doering OC, Tyner WE (2015) The economic competitiveness and emissions of battery electric vehicles in China. Appl Energy 156:666-675. doi: 10.1016/j.apenergy.2015.07.063

9. Faria R, Marques P, Moura P, Freire F, Delgado J, Almeida AT De (2013) Impact of the electricity mix and use pro fi le in the life-cycle assessment of electric vehicles. Renew Sustain Energy Rev 24:271-287. doi: 10.1016/j.rser.2013.03.063

10. Ou X, Zhang X, Chang S (2010) Scenario analysis on alternative fuel/vehicle for China's future road transport: Life-cycle energy demand and GHG emissions. Energy Policy 38:3943-3956. doi: 10.1016/j.enpol.2010.03.018

11. Samaras C, Meisterling K (2008) Life Cycle Assessment of Greenhouse Gas Emissions from Plug-in Hybrid Vehicles: Implications for Policy Life Cycle Assessment of Greenhouse Gas Emissions from Plug-in Hybrid Vehicles: Implications for Policy. Environ Sci Technol 42:3170-3176. doi: 10.1021/es702178s

12. Hawkins TR, Singh B, Majeau-Bettez G, Stromman AH (2013) Comparative Environmental Life Cycle Assessment of Conventional and Electric Vehicles. J Ind Ecol 17:53-64. doi: 10.1111/j.1530-9290.2012.00532.x

13. Guo XR, Cheng SY, Chen DS, Zhou Y, Wang HY (2010) Estimation of economic costs of particulate air pollution from road transport in China. Atmos Environ 
44:3369-3377. doi: 10.1016/j.atmosenv.2010.06.018

14. Yang S, He LY (2016) Fuel demand, road transport pollution emissions and residents' health losses in the transitional China. Transp Res Part D Transp Environ 42:45-59. doi: $10.1016 /$ j.trd.2015.10.019

15. Howey DA, Martinez-Botas RF, Cussons B, Lytton L (2011) Comparative measurements of the energy consumption of 51 electric, hybrid and internal combustion engine vehicles. Transp Res Part D Transp Environ 16:459-464.

16. Fæhn T, Bruvoll A (2009) Richer and cleaner-At others' expense? Resour Energy Econ 31:103-122. doi: 10.1016/j.reseneeco.2008.11.001

17. Ghertner DA, Fripp M (2007) Trading away damage: Quantifying environmental leakage through consumption-based, life-cycle analysis. Ecol Econ 63:563-577. doi: 10.1016/j.ecolecon.2006.12.010

18. Nakano M, Chua ST (2011) Design of Taxation to Promote Electric Vehicles in Singapore. IFIP Adv Inf Commun Technol 1:359-367.

19. International Energy Agency (IEA) (2015) Global EV Outlook 2016. Paris

20. Ji S, Cherry CR, Bechle MJ, Wu Y, Marshall JD (2012) Electric vehicles in China: Emissions and health impacts. Environ Sci Technol 46:2018-2024. doi: $10.1021 /$ es $202347 \mathrm{q}$

21. Nissan Official Website (2017) PRESS Realease: Nissan Intelligent Mobility at CES. http://nissannews.com/en-US/nissan/usa/channels/us-nissan-2017-ces/releases/presskit-nissan-intelligent-mobility-at-ces. Accessed 15 Jun 2017

22. International Energy Agency (IEA) (2016) Electricity Information 2016. IEA Stat. doi: http://dx.doi.org.ezproxy.lib.ryerson.ca/10.1787/electricity-2011-en

23. Ministry of Energy of Poland (2017) Electromobility Development Plan for Poland. Warsaw

24. Polish Ministry of Economy (2016) Polish Energy Policy till 2050. Warsaw

25. IEA Clean Coal Centre (2015) Emission standards: Poland.

26. Nissan: Material. In: Nissan Off. Website. www.nissan-cdn.net Accessed 18 Aug 2016

27. Chen Y (2005) China Motorization Trends. In: Grow. Greenh. Prot. Clim. by Putt. Dev. First. World Resources Institute, pp 49-67

28. FIA Foundation (2003) The Automobile and Society.

29. Department for Transport (2015) National Travel Survey: England 2014. London

30. Chlopek Z, Waskiewicz J (2013) Projections of the Fuel Consumption by the Road Transport in Poland. J KONES Powertrain Transp 20:33-40.

31. Shipping Quotation Platform (2017) Shipping Quotation. In: Searates.com Website. https://www.searates.com/. Accessed 11 Mar 2017

32. Belson K (2012) Around the World With 5,500 Cars. New York Times Online 1-4.

33. Toyofuji Shipping Co Ltd. (2017) Service Fleet of Toyofuji Corp. In: Toyofuji Shipp. Website. www.toyofuji.co.jp/english/works/fleet2.html. Accessed 13 Feb 2017

34. Moreno-Gutiérrez J, Calderay F, Saborido N, Boile M, Rodríguez Valero R, DuránGrados V (2015) Methodologies for estimating shipping emissions and energy consumption: A comparative analysis of current methods. Energy 86:603-616.

35. McKay DJC (2008) Sustainable Energy - without the hot air. Cambridge

36. Vidal J (2009) Health risks of shipping pollution have been 'underestimated '. Guard $1-5$. 